\title{
THE ROLE OF KNOWLEDGE MANAGEMENT AND EMPLOYEE COMPETENCY TOWARDS ORGANIZATION PERFORMANCE WITH INNOVATION AS A MEDIATING VARIABLES IN LOCAL WATER COMPANY (PDAM) KETAPANG REGENCY WEST KALIMANTAN
}

\author{
Endah Setyowati \\ Student Master of Management \\ Universitas Krisnadwipayana \\ Campus Unkris Jatiwaringin \\ PO BOX 7774/Jat CM Jakarta 13077 \\ Indonesia \\ Suharto \\ Associate Professor \\ Universitas Krisnadwipayana \\ Campus Unkris Jatiwaringin \\ PO BOX 7774/Jat CM Jakarta 13077 \\ Indonesia \\ Iwan Kurniawan Subagja \\ Lecturer and Reseacher \\ Universitas Krisnadwipayana \\ Campus Unkris Jatiwaringin \\ PO BOX 7774/Jat CM Jakarta 13077 \\ Indonesia

\begin{abstract}
A B S T R A C T
This study aims to: 1) test and analyze the role of knowledge management and competence in innovation, 2) test and analyze the role of knowledge management and competence on organizational performance, 3) test and analyze the role of innovation on organizational performance, 4) test and analyze the role of management knowledge of organizational performance through innovation, 5) testing and analyzing the role of competence on organizational performance through innovation, and 6) testing and analyzing the role of knowledge management and employee competence on organizational performance through innovation at PDAM Ketapang Regency. The research was conducted by PDAM Ketapang Regency employees, totaling 71 employees. The sampling technique uses saturated samples. Methods of data analysis using descriptive analysis and quantitative analysis with path analysis.

The results showed that: 1) there was an influence on the role of knowledge management and competence on innovation, 2) there was an influence on the role of knowledge management and competence on organizational performance, 3) there was an influence on the role of innovation on organizational performance, 4) there was an influence on the role of knowledge management on organizational performance through innovation, 5) there is an influence on the role of competence on organizational performance through innovation, and 6) there is an influence on the role of knowledge management and employee competence on organizational performance through
\end{abstract} \\ innovation at PDAM Ketapang Regency.
}

A R T I C L E I N F O
Article history: Article
Received
Revised
Accepted: September, 2020
DOI: $10.47742 /$ ijbssr.v1 n2p1

Keywords : Knowledge Management, Competence, Innovation, Organizational Performance

\section{Introduction}

Drinking water is a basic necessity for humans, which must be available in sufficient quantity, a quality that meets the requirements, and continuous service time. The government to accelerate the increase in the coverage of drinking water services has mandated the National Medium Term Development Plan (RPJMN) Phase III (2015-2019) which proclaims a movement to achieve $100 \%$ safe access to drinking water by the end of 2019 . Achievement of access to drinking water in 2017 is now reached $71.14 \%$. Based on the Regulation of the Minister of Public Works Number 16 of 2005, the Agency for the Improvement of the Implementation of the Drinking Water Supply System
(BPPSPAM) has a function, one of which is to evaluate the quality and performance standards of SPAM administration services. In this regulation, BPPSPAM as an agency formed to assist the Government in achieving more detailed SPAM regulatory objectives. The role of BPPSPAM in achieving the objectives of regulating the development of Drinking Water Supply Systems (SPAM), one of which is as stated in Article 4 letter (a), namely: "Encouraging improved performance of SPAM administration services." Government Regulation Number 16 of 2005 concerning Development of the Supply System Drinking water is reaffirmed by the Minister of Public Works Regulation No. 294 / PRT / M / 2005, namely in Article 8 


\section{Vol: 1, Issue: 2} October $/ 2020$

https://ijbssrnet.com/index.php/ijbssr

letter (c) with the same description, namely "Evaluating quality standards and service performance of SPAM administration." The concept of performance is basically can be seen from two aspects, namely employee performance, and organizational performance. Performance is a description of the level of achievement of task implementation within an organization, to realize the goals, objectives, mission, and vision of the organization (Bastian, 2001: 329). The concept of performance can be defined as an achievement of results or degree of accomplishments (Rue and Byars, 1981 in Keban 1995). This means that the performance of an organization can be seen from the extent to which the organization can achieve its goals based on predetermined goals.

Determination of performance status is carried out by comparing the total value of the performance obtained with predetermined criteria, namely: healthy, unhealthy, and sick with a description as follows:

- Healthy PDAM performance, if it has a total performance score of $>2.8$;

- PDAM performance is not healthy if it has a total performance value between 2.2 to 2.8 ;

- PDAM performance is sick, if it has a total performance value $<2.2$

PDAM Ketapang Regency is a Regional Owned Enterprise of Ketapang Regency, West Kalimantan Province, which is tasked with meeting the drinking water needs of the community in Ketapang Regency and always strives to be able to meet the standards of Quality. Quantity and service continuity to achieve the best service for the Ketapang community.

Based on the performance appraisal conducted by BPPSPAM for the last 4 years (2015, 2016 and 2017, and 2018 PDAM Ketapang Regency is in a "less healthy" performance condition. PDAM Performance Assessment is based on 4 (four) aspects, namely Operational Aspects, Financial aspects, Aspects Services, and HR aspects.

Performance is a translation of "performance" which is often interpreted as appearance, demonstration, or achievement. Performance is the level of achievement of organizational goals on an ongoing basis (Kaban, 2004). Meanwhile, according to Mahsun (2006) performance is a description of the level of achievement of the implementation of a program, activity, or policy in realizing the goals, objectives, mission, and vision of the organization as stated in the strategic planning of an organization. Mustopadjadja (2003) states that several types of indicators can be used in measuring organizational performance, namely as follows: input indicators, process indicators, output indicators, outcome indicators, and benefits indicators.

PDAM Ketapang Regency is a Regional Owned Enterprise (BUMD) of Ketapang Regency whose performance depends on the quality of human resources or employees. According to Puryantini, Arfati, and Bambang Tjahjadi, 2017, employees are also a source of knowledge, innovation, and renewal, which depend on informal communication between individuals and are people-centric operations. This is why the spread of knowledge is often interrupted, so that important information cannot be conveyed properly between individuals. For this reason, knowledge in improving performance needs to be managed and documented using the concept of knowledge management which is a series of activities used by organizations or institutions to identify, create, explain and distribute knowledge that will be reused, known, and used, studied within the organization. These activities are usually related to organizational goals and are aimed at achieving a specific outcome such as shared knowledge, increased performance, competitive advantage, or a higher level of innovation.

Referring to research from Puryantini, Arfati, and Tjahjadi (2017), so that organizations can develop services independently, there must be knowledge management, skills, and human resource capabilities to absorb science and technological developments. The purpose of Knowledge Management is to make it easy for employees to utilize, explore, and share knowledge so that the process of creativity and service innovation in PDAM Ketapang Regency will be pushed more broadly and each employee quickly increases their competence in the hope that it will give birth to innovations in service to a customer.

The application of knowledge management will make continuous performance improvements, is one of the management tools that can be used to support the achievement of organizational goals and show competitive advantages to create a good organizational performance (Megantoro et al., 2014). The knowledge-based view of resources is an approach to understanding the relationship between organizational capabilities and organizational performance. Knowledge-based resource theory states that knowledge is the most strategically significant company resource. Knowledge-based resources are usually difficult for other organizations to imitate and as a source of competitive advantage. Knowledge management has emerged as a source of sustainable competitive advantage (J. Barney, 1991).

Wibowo (2012: 104) states that competence is the ability of a person to carry out the job given to him well. Employee competencies include educational background, experience, and training obtained related to skill needs. To fulfill competency requirements, PDAM management considers employee experience to be one of the considerations in placing positions/assignments. In addition to obtaining specific skills, several employees have been included in training/coaching programs according to the required competencies. The number of employees who are included in the training is not the same every year, because it depends on the suitability of the competency training being offered with the type of training needed, and it depends on the PDAM's ability to pay for the competency training offered.

\section{Literature Review}

\section{Organizational Performance}

Organizational performance is an indicator of the level of achievement that can be achieved and reflects the success of an organization, as well as the results achieved from the behavior of organizational members. Performance can also be said to be a result (output) of a particular process carried out by all 


\section{Vol: 1, Issue: 2} October $/ 2020$

https://ijbssrnet.com/index.php/ijbssr DOI: 10.47742/ijbssr.v1n2p1

organizational components on certain sources used (input). Furthermore, performance is also the result of a series of process activities carried out to achieve certain organizational goals. For an organization, performance is the result of collaborative activities among members or organizational components to achieve organizational goals.

Surjadi (2009: 7) states that organizational performance is the totality of the work achieved by an organization to achieve organizational goals, meaning that the performance of an organization can be seen from the extent to which the organization can achieve goals based on predetermined goals. According to Sobandi (2006: 176), Organizational performance is something that has been achieved by the organization within a certain period, both related to input, output, outcome, benefit, and impact.

Organizational performance that has been implemented with a certain level of achievement should be following the mission that has been set as the basis for carrying out the assigned task. Thus, Keban (2014: 192) says that performance is the level of achievement of the results or the degrees of accomplishment. The organizational performance or company performance is an indicator of the level of achievement that can be achieved and reflects the success of the manager/entrepreneur. Gibson (2010: 179) states that performance is the result achieved from the behavior of organizational members. So organizational performance is the result that the organization wants from the behavior of the people in it. Assessment of organizational performance can be viewed from the company's financial ratios.

The work achieved by an agency in carrying out its duties within a certain period, whether related to input, output, outcome, benefit, or impact with responsibility can facilitate the direction of structuring government organizations. The results of the work achieved by the agency with full responsibility will result in effective and efficient performance improvement. Government organizations use tools, the theory used is Sobandi's (2006: 179) theory of performance. The organizational performance indicators according to Sobandi (2006: 179-181):

\section{a. Output}

The output is something that is expected to be achieved directly from an activity in the form of physical or non-physical.

\section{b. Results}

The outcome is measuring the achievement of results that occur due to the provision of services. Anything that reflects the functioning of the activity output in the medium term (direct effect).

\section{c. Business Linkage with Achievement}

The relationship between business and achievement is a measure of efficiency that links business to service output.

\section{Knowledge Management}

Davidson and Voss (2002) define knowledge management as a system that allows companies to absorb knowledge, experience, and creativity, a process that provides a way for companies to recognize the key intellectual assets that exist. According to Soleh (2011), knowledge management indicators are:
1. Identification of knowledge is the desire of a person or group to be the same as others. Another meaning is wanting to find common knowledge and an unlimited amount of information.

2. Knowledge creation, namely building neatly structured practices to manage an organization to develop it

3. Sharing knowledge, is an important process in the progress of today's organizations, because it spreads intellectual capital for the entire organization, for the gains generated by individuals or groups to carry out new useful and useful innovations.

4. The use of knowledge is the use of a result that has been searched for, created, then shared so that it makes it easier to obtain the right information at the right time for smooth organizational performance

\section{Competence}

Sutrisno (2010: 202) states that etymologically, employee competence is defined as an indicator of the skills or excellence of a leader or staff who has good skills, knowledge, and behavior. Sedarmayanti (2012: 112) competence is a fundamental characteristic that a person has that directly affects, or can predict excellent performance. In other words, competence is what outstanding performers do more often, in more situations, with better results than what policy assessors do. From some of the definitions above, it can be concluded that competence is the basic expertise and skills as well as the experience of a person, staff, or leader that can influence them in carrying out their work or other tasks effectively and efficiently or following predetermined company standards.

According to Moeheriono (2012: 57), states that in detail there are five competency indicators that all individuals must possess, namely as follows:

a. Task Skills, namely the ability to carry out routine tasks following workplace standards.

Task Management Skills, namely the skills to manage a series of different tasks that arise in a job.

b. Contingency Management Skills, namely the skills to take quick and appropriate action when a problem arises at work. Job Role Environmental Skills, namely skills to work together and maintain a comfortable work environment.

c. Transfer Skills, namely skills to adapt to a new work environment.

Based on the above understanding, it is synthesized that competence is a basic characteristic possessed by an individual who is causally related to fulfilling the criteria needed to occupy a position.

\section{Innovation}

According to Schumpeter (1934) in Dewanto et al (2014: 3 ), as a new combination of production factors created by entrepreneurs and thought innovation is an important driving force in economic growth. The Schumpeter innovation concept involves product innovation, process innovation, market innovation, the use of raw materials, and obtaining these raw materials using innovation in the organization. 


\section{Vol: 1, Issue: 2} October $/ 2020$

https://ijbssrnet.com/index.php/ijbssr DOI: $10.47742 / i j b s s r . v 1 n 2 p 1$

Drucker (1986), innovation is a specific tool for business actors to take advantage of change as a different business opportunity or service. Innovation can be presented as a science, can be learned, and can be put into practice. Business actors need to deliberately look for sources of innovation, change, and symptoms that indicate opportunities for successful innovation. They also need to know and apply the principles of successful innovation.

Kotler (2015: 121) defines innovation as something related to goods, services, or ideas that someone feels new. Although this idea has been around for a long time, it can be said to be an innovation for people who have just seen or felt it. Furthermore, according to Kotler (2015: 121) companies can innovate in the form of:

1. Product innovation (goods, services, and ideas)

2. Management innovation (work process, production process, finance, marketing) Innovation indicators according to Schumptemer (1934) are:

3. Introducing new products or qualitative changes to existing products,

4. Introducing new processes to the industry,

5. Opening up new markets

6. Developing new sources of supply for raw materials or other inputs, 5. Changes in industrial organizations

\section{Research Methods}

\section{Time and Location of Research}

The research was conducted from May to October 2019 Research Design

The research design is a blueprint for the researcher. Therefore, it needs to be prepared before the research is carried out, because it is a systematic guide and direction to researchers about what activities, when, where, and how should be carried out (Rivai and Guswandi, 2016; 10). The research design also describes what it is about certain variables, circumstances, and phenomena so that in this study, in-depth information can be obtained on the relationship or relationship between the independent (endogenous) variables, namely $\mathrm{X}_{1}$ (Knowledge Management), $X_{2}$ (Competence), the dependent variable, namely (Y) Organizational Performance and the mediating variable, namely $\mathrm{X}_{3}$ (Innovation).

This research uses causality and correlational approaches. The causality research design is structured to examine the possibility of a causal relationship between variables. Meanwhile, the correlational approach is made to investigate possible relationships that occur between variables by taking into account the magnitude of the correlation.

\section{Population and Sample}

Sugiyono (2017: 85) says that population is a generalization area consisting of objects/subjects that have certain quantities and characteristics that are determined by researchers to be studied and then draw conclusions. According to Arikunto, $(2010 ; 173)$, the population is the entire research subject (Arikunto, 2010: 173). The population is all employees of the PDAM Ketapang Regency, amounting to 71 employees. The sample used in this study was obtained by using the nonprobability sampling technique with saturated or census samples. According to Riduwan (2012: 64), saturated sampling is a sampling technique when all populations are used as samples and it is also known as a census. Arikunto (2010: 134) further states that if the subject is less than 100, it is better to take all of them so that the research is a population study.

The sample used by researchers in this study were employees of PDAM Ketapang Regency, West Kalimantan Province. The sample taken in this study is the total number of employees as many as 71 people.

\section{Data Collection Technique}

In this study, the data collection technique used was a questionnaire. This method is done by providing a list of questions, then the list of questions is pulled back by the researcher to be used as primary data for this study. Data for this purpose were filtered through a list of questions presented using a Likert Scale.

\section{Data Processing Techniques}

For research analysis to produce correct information, because the data received is still raw material, the data must be processed first. A questionnaire depends on the quality of the data used in the test. Research data will not be useful if the instrument that will be used to collect research data does not have validity and reliability is high.

\section{Research Results and Discussion}

1. Analysis of the role of knowledge management and competence in innovation (Sub Structure I)

To analyze the role of knowledge and competence in innovation, 2 (two) stages of analysis were carried out, namely calculating the path coefficient and testing the hypothesis followed by concluding.

Based on the results of data analysis, the significance value of the knowledge management variable $\left(X_{1}\right)$ is Sig. $=0.000$ which is less than 0.05. Likewise for the significance value of the employee competency variable $\left(\mathrm{X}_{2}\right)$, namely Sig. $=0.001$ which is smaller than 0.05 . These results conclude that the knowledge management variable $\left(\mathrm{X}_{1}\right)$ has a significant effect on innovation $\left(X_{3}\right)$. Likewise, the employee competency variable $\left(X_{2}\right)$ has a significant effect on innovation $\left(\mathrm{X}_{3}\right)$. The magnitude of the correlation coefficient $\mathrm{R}=0.880$ (positive value and greater than 0.07 ) which concludes that the relationship between knowledge management $\left(\mathrm{X}_{1}\right)$ and competence $\left(\mathrm{X}_{2}\right)$ together and innovation $\left(X_{3}\right)$ is strong and unidirectional (increased knowledge management). $\left(\mathrm{X}_{1}\right)$ and competence $\left(\mathrm{X}_{2}\right)$ together will also affect increasing innovation (X3).

Also, note that the $\mathrm{R}_{2}$ or $\mathrm{R}$ square value is 0.775 . This indicates that the contribution or influence of knowledge management $\left(\mathrm{X}_{1}\right)$ and employee competence $\left(\mathrm{X}_{2}\right)$ together on innovation $\left(\mathrm{X}_{3}\right)$ is $77.5 \%$. While the remaining $22.5 \%$ is a contribution from other variables not included in the study. Thus the path diagram for the substructure I obtained 


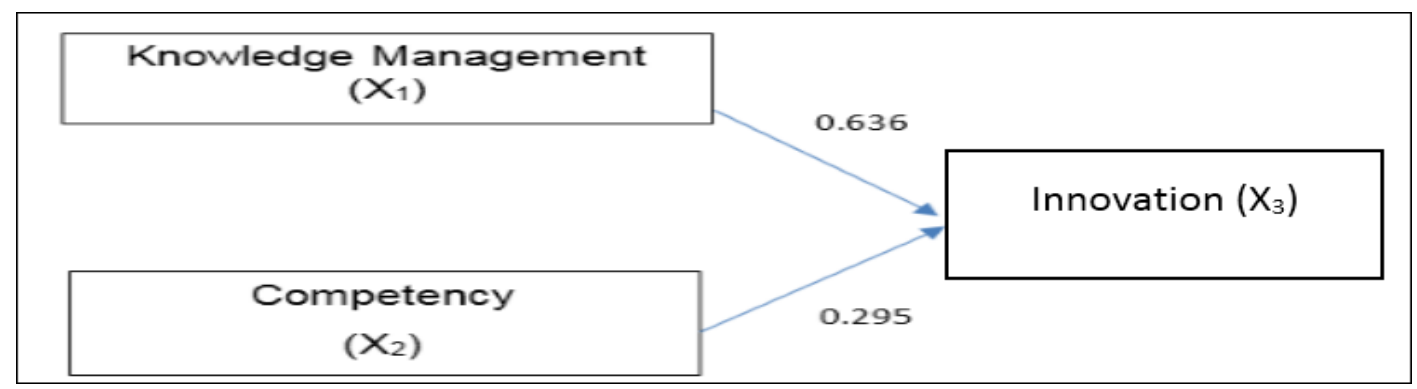

Figure 1. Sub Structure Path Diagram 1

2. Analysis of the role of knowledge management, and the innovation variable (X3) has a significant effect on employee competence, and innovation on organizational performance (Y).

\section{organizational performance (Equation of Sub}

Structure 2)

The role of knowledge management variables, employee competence, on organizational performance in a combination that the significance value of the knowledge management variable (X1) is Sig. $=0.002$ which is smaller than 0.05. Likewise, for the significance value of the employee competency variable (X2), namely Sig. $=0.006$ which is smaller than 0.05 and the innovation variable $(\mathrm{X} 3)$ is Sig. $=0.000$ which is smaller than 0.05 .

These results conclude that the knowledge management variable (X1) has a significant effect on organizational performance (Y). Likewise, the employee competency variable (X2) has a significant effect on organizational performance (Y)
Vol: 1, Issue: 2

October $/ 2020$

https://ijbssrnet.com/index.php/ijbssr DOI: 10.47742/ijbssr.v1n2p1 The magnitude of the correlation coefficient $\mathrm{R}=0.929$
(positive value and greater than 0.07 ) which concludes that the relationship between knowledge management (X1), employee competence (X2), and innovation (X3) together and organizational performance $(\mathrm{Y})$ is strong and unidirectional (increased knowledge management (X1), employee competence (X2) and innovation (X3) together will also play a role in improving organizational performance $(\mathrm{Y})$ ).

Also, note that the value of $\mathrm{R} 2$ or $\mathrm{R}$ square is 0.863 . This indicates that the contribution or contribution of the role of knowledge management (X1), employee competence (X2), and innovation $(\mathrm{X} 3)$ together on organizational performance $(\mathrm{Y})$ is $86.3 \%$. While the remaining $13.7 \%$ is the contribution of other variables not included in the study. Thus, the path diagram for Sub Structure II is obtained:

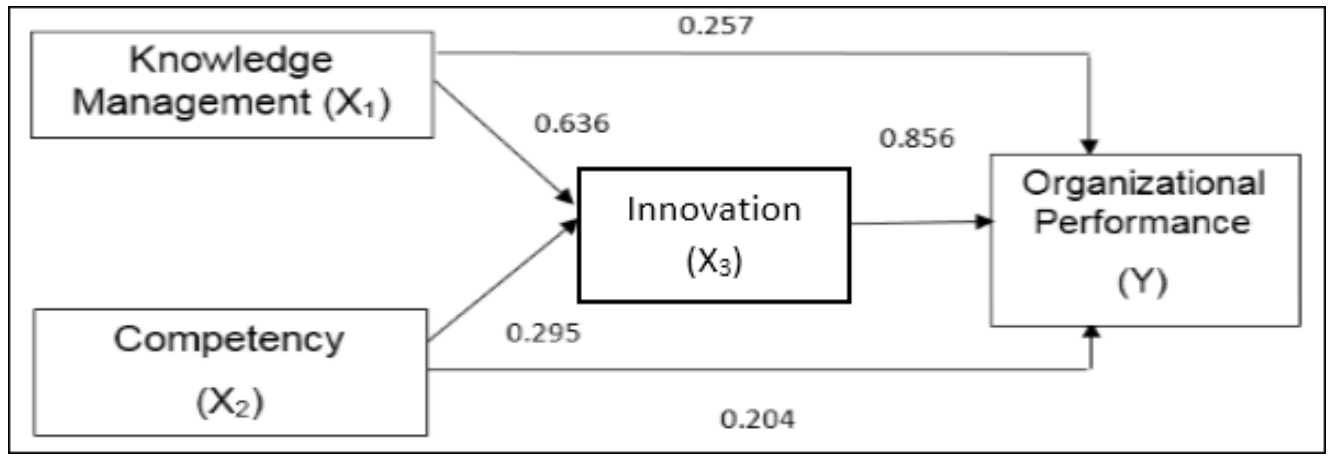

Figure 2. Sub Structure Path Diagram II

\section{Hypothesis Test}

\section{1). Knowledge management and competence play a role} in innovation in PDAM Ketapang Regency.

To find out whether knowledge management and competence have an effect on innovation in PDAM Ketapang Regency, it is necessary to use the F / ANOVA test. The test results of each variable show the simultaneous test results of $\mathrm{p}=$ 0.000 which mean significant ( $\mathrm{p}<0.05$ ), while F Count 138.775> F Table 3.195 at the 5\% significance level, meaning that there is a linear relationship between knowledge management and employee competence on innovation. So it can be stated that the knowledge management variable and employee competence have a role in the innovation variable. Thus $\mathrm{H} 0$ is rejected and $\mathrm{H} 1$ is accepted, so it can be concluded that knowledge management and employee competence play a role in innovation in PDAM Ketapang Regency.
2). Knowledge management and competence have a simultaneous effect on organizational performance in PDAM Ketapang Regency

To find out whether knowledge management and employee competence have a simultaneous effect on organizational performance in PDAM Ketapang Regency, it is necessary to use the F / ANOVA test. The test results of each of the SPSS output results showed the simultaneous test results of $p$ $=0.000$ which mean significant $(\mathrm{p}<0.05)$, while $\mathrm{F}$ Count $118.013>$ F Table 3.195 at the 5\% significance level, meaning that there is a linear relationship between knowledge management and competence on organizational performance so that it can be stated that the knowledge management variables and employee competencies have a role in the organizational performance variables. Thus $\mathrm{H} 0$ is rejected and $\mathrm{H} 1$ is accepted, so it can be concluded that knowledge management and 


\section{Vol: 1, Issue: 2}

October $/ 2020$

https://ijbssrnet.com/index.php/ijbssr

DOI: 10.47742/ijbssr.v1n2p1

employee competence play a role in organizational performance in PDAM Ketapang Regency.

3. Innovation affects organizational performance in

\section{PDAM Ketapang Regency}

To find out whether innovation has a direct effect on organizational performance in PDAM Ketapang Regency, it is necessary to use the F / ANOVA test. The test results of each variable of the SPSS output results show the simultaneous test results of $\mathrm{p}=0.000$ which mean significant $(\mathrm{p}<0.05)$, while $\mathrm{F}$ Count 363,371> F Table 3.195 at the 5\% significance level, meaning that there is a linear relationship between innovation and organizational performance. So it can be stated that the innovation variable has a role in the organizational performance variable. Thus $\mathrm{H} 0$ is rejected and $\mathrm{H} 1$ is accepted, so it can be concluded that innovation plays a role in organizational performance in PDAM Ketapang Regency.

4). Knowledge management affects organizational performance in PDAM Ketapang Regency

To find out whether knowledge management has a direct effect on organizational performance in PDAM Ketapang Regency, it is necessary to use the F / ANOVA test. The test results of each variable of the SPSS output results show the simultaneous test results of $\mathrm{p}=0.000$ which mean significant $(\mathrm{p}$ $<0.05$ ), while F Count 26.503> F Table 3.195 at the 5\% significance level, meaning that there is a linear relationship between knowledge management and performance organization so that it can be stated that knowledge management variables have a role in organizational performance variables. Thus $\mathrm{H} 0$ is rejected and $\mathrm{H} 1$ is accepted, so it can be concluded that knowledge management plays a role in organizational performance in PDAM Ketapang Regency.

5). Competence affects organizational performance in PDAM Ketapang Regency

To find out whether the employee competency variable has a direct effect on organizational performance in PDAM
Ketapang Regency, it is necessary to use the F / ANOVA test. The test results of each variable of the SPSS output results show the simultaneous test results of $\mathrm{p}=0.000$ which mean significant ( $p<0.05$ ), while F Count 5.812> F Table 3.195 at the 5\% significance level, meaning that there is a linear relationship between competence and organizational performance. So it can be stated that the competency variable has a role in the organizational performance variable. Thus $\mathrm{H} 0$ is rejected and $\mathrm{H} 1$ is accepted, so it can be concluded that employee competence plays a role in organizational performance in PDAM Ketapang Regency.

6). Knowledge management, employee competence, and innovation simultaneously influence organizational performance in PDAM Ketapang Regency.

To find out whether knowledge management, employee competence, and innovation play a role in organizational performance in PDAM Ketapang Regency, it is necessary to use the F / ANOVA test. The test results for each variable of the Ftest results at the SPSS output can be seen in the Anova Table. Based on the results of the SPSS output, the simultaneous test results showed $\mathrm{p}=0.000$ which means significant $(\mathrm{p}<0.05)$, while F Count 140.970> F Table 3.195 at the 5\% significance level, meaning that there is a linear relationship between knowledge management, employee competence, and innovation towards organizational performance so it can be stated that the variables of knowledge management, employee competence, and innovation have a role in organizational performance variables. Thus H0 is rejected and H1 is accepted, so it can be concluded that knowledge management, employee competence, and innovation simultaneously play a role in organizational performance in PDAM Ketapang Regency.

\section{Direct Effect and Indirect Effect}

The structural equation in this model is:

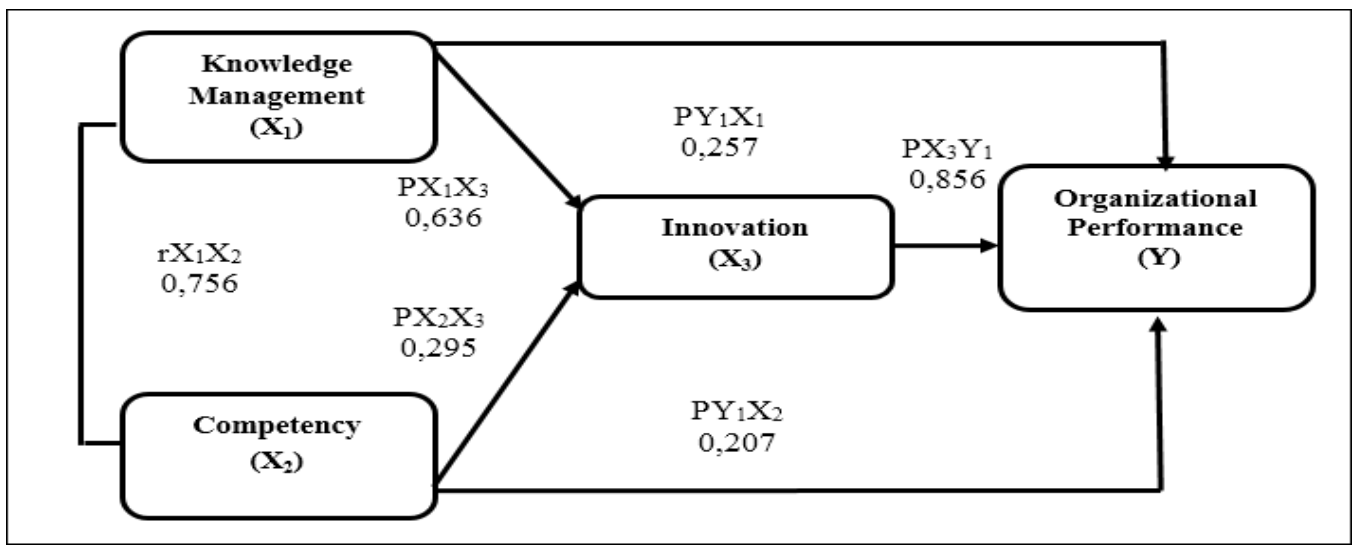

Figure 3. Structural Equations 
The results of the analysis show that all direct, indirect, and total pathways in the table above play a significant role, it is concluded that:

1. Analysis of the role of knowledge management (X1) on innovation (X3):

Obtained a significance value of Sig. $=0.000<0.05$, so it can be concluded that there is a direct significant role in knowledge management (X1) on innovation (X3).

2. Analysis of the role of employee competence (X2) on innovation (X3):

Obtained a significance value of Sig. $=0.001<0.05$ so it can be concluded that there is a direct significant role of competence (X2) on innovation (X3).

3. Analysis of the role of knowledge management (X1) on organizational performance $(\mathrm{Y})$ :

Obtained a significance value of Sig. $=0.002<0.05$, so it can be concluded that there is a direct significant role in knowledge management (X1) on organizational performance $(\mathrm{Y})$.

4. Analysis of the role of employee competence (X2) on organizational performance $(\mathrm{Y})$ :

Obtained a significance value of Sig. $=0.006<0.05$ so it can be concluded that there is a direct significant role of employee competence (X2) on organizational performance $(\mathrm{Y})$.

5. Analysis of the role of innovation (X3) on organizational performance $(\mathrm{Y})$ :

Obtained a significance value of Sig. $=0.000<0.05$, so it can be concluded that there is a direct significant influence of innovation (X3) on organizational performance $(\mathrm{Y})$.

6. Analysis of the role of knowledge management (X1) through innovation (X3) on organizational performance $(Y)$ :

Based on the results of the above calculations, it is known that the value of the direct role is 0.257 and the value of the indirect role is 0.544 which means that the value of the indirect role is greater than the value of the direct role.

Thus, these results indicate that indirect knowledge management (X1) through innovation (X3) has a significant role in organizational performance $(\mathrm{Y})$. In other words, these results indicate that indirectly knowledge management (X1) through innovation (X3) has a significant role in organizational performance $(\mathrm{Y})$.

7. Analysis of the role of employee competence (X2) through innovation (X3) on organizational performance (Y): Discussion

\section{Competence in Innovation}

\section{The Role of Knowledge Management and}

Based on the results of the description analysis, knowledge identification provides the greatest support for the formation of knowledge management variables, namely the knowledge gained is sufficient to carry out tasks and activities in PDAM. The competency variable shows that the task skill indicator makes a major contribution to the formation of competency variables, namely the competence/ability of employees following their respective responsibilities/duties and is following what is needed in the PDAM Ketapang Regency. Whereas the innovation variable shows that the management innovation indicator provides the greatest value for the formation of the innovation variable, namely innovation is carried out by organizational control from PDAM Ketapang (central) to the unit as well as the commitment of the local government to improve the management of PDAM Ketapang Regency for organizational strengthening. Based on the path analysis, it shows that knowledge and competency management can have an impact on increasing innovation in PDAM Ketapang Regency. The results of the study are in line with research conducted by Afqarina (2018), Puryantini, Arfati, and Tjahjadi (2017), Noviyanti and Mulyanto (2017), Araswati and Widiartanto (2016).

2. The Role of Knowledge Management and Competence on Organizational Performance

Based on the results of the descriptive analysis, it shows that the output indicators provide a big contribution to the formation of organizational performance variables, namely an increase in the number and customer satisfaction. Based on the results of the description analysis, the identification of knowledge provides the greatest support for the formation of knowledge management variables, namely the knowledge gained is sufficient to carry out tasks and activities in the PDAM. The competency variable shows that the task skill indicator provides a major contribution to the formation of competency variables, namely the competence/ability of employees following their respective responsibilities/duties and is following what is needed in the PDAM Ketapang Regency. Based on the path analysis, it shows that knowledge and competency management can have an impact on improving organizational performance in PDAM Ketapang Regency. The results of the study are in line with research conducted by Siagian (2019), Hidayat (2019), Afqarina (2018), Araswati and Widiartanto (2016), Ekawati and Puspitowati (2016), and Adha \& Ibrahim (2013).

\section{Performance}

\section{The Role of Innovation on Organizational}

Based on the results of the descriptive analysis, it shows that the output indicators provide a big contribution to the formation of organizational performance variables, namely an increase in the number and customer satisfaction. Whereas the innovation variable shows that the management innovation indicator provides the greatest value for the formation of the innovation variable, namely innovation is carried out by organizational control starting from the Ketapang PDAM (central) to the unit as well as the commitment of the local government to improve the management of PDAM Ketapang Regency for organizational strengthening. Based on the path analysis, it shows that innovation can have an impact on improving organizational performance in PDAM Ketapang Regency. The results of the study are in line with research conducted by Siagian (2019), Afqarina (2018), Noviyanti, and Mulyanto (2017), Araswati, and Widiartanto (2016), Ekawati and Puspitowati (2016), and Adha \& Ibrahim (2013). 


\section{Vol: 1, Issue: 2}

October $/ 2020$

https://ijbssrnet.com/index.php/ijbssr

DOI: 10.47742/ijbssr.v1n2p1

\section{The Role of Knowledge Management} Organizational Performance Through Innovation

Based on the results of the description analysis, the identification of knowledge provides the greatest support for the formation of knowledge management variables, namely the knowledge gained is sufficient to carry out tasks and activities in the PDAM. Based on the results of the descriptive analysis, it shows that the output indicators provide a big contribution to the formation of organizational performance variables, namely an increase in the number and customer satisfaction. Whereas the innovation variable shows that the management innovation indicator provides the greatest value for the formation of the innovation variable, namely innovation is carried out by organizational control starting from the Ketapang PDAM (central) to the unit as well as the commitment of the local government to improve the management of PDAM Ketapang Regency for organizational strengthening. Based on the path analysis, it shows that innovation can have an impact on improving knowledge management on organizational performance in PDAM Ketapang Regency. The results of the study are in line with research conducted by Siagian (2019), Afqarina (2018), Noviyanti, and Mulyanto (2017), Araswati, and Widiartanto (2016), Ekawati and Puspitowati (2016), and Adha \& Ibrahim (2013).

\section{The Role of Competence on Organizational Performance through Innovation}

Based on the results of the descriptive analysis, it shows that the output indicators provide a big contribution to the formation of organizational performance variables, namely an increase in the number and customer satisfaction. Based on the results of the description analysis, the identification of knowledge provides the greatest support for the formation of knowledge management variables, namely the knowledge gained is sufficient to carry out tasks and activities in the PDAM. Based on the path analysis shows that competence can have an impact on improving organizational performance through innovation in PDAM Ketapang Regency. The results of the study are in line with research conducted by Siagian (2019), Afqarina (2018), Noviyanti, and Mulyanto (2017), Araswati, and Widiartanto ( 2016), Ekawati and Puspitowati (2016), and Adha \& Ibrahim (2013).

\section{The Role of Knowledge Management and Competence on Organizational Performance through Innovation}

Based on the results of the descriptive analysis, it shows that the output indicators provide a big contribution to the formation of organizational performance variables, namely an increase in the number and customer satisfaction. Based on the results of the analysis of the description of the knowledge identification indicator, it provides the greatest support for the formation of knowledge management variables, namely the knowledge gained is sufficient to carry out tasks and activities in the PDAM. The competency variable shows that the task skill indicator provides a major contribution to the formation of competency variables, namely the competence/ability of employees following their respective responsibilities/duties and is following what is needed in the PDAM Ketapang Regency. Whereas the innovation variable shows that the management innovation indicator provides the greatest value for the formation of the innovation variable, namely innovation is carried out by organizational control starting from the Ketapang PDAM (central) to the unit as well as the commitment of the local government to improve the management of PDAM Ketapang Regency for organizational strengthening. Based on the path analysis, it shows that innovation has an increased impact between knowledge management and competence in improving organizational performance in PDAM Ketapang Regency. The results of the study are in line with research conducted by Siagian (2019), Hidayat (2019), Afqarina (2018), Araswati and Widiartanto (2016), Ekawati and Puspitowati (2016), and Adha \& Ibrahim (2013).

\section{Conclusions and Recommendations}

\section{Conclusion}

Based on the results of research on the role of knowledge management and employee competence on organizational performance with innovation as a mediating variable at PDAM Ketapang, the following conclusions can be drawn:

\section{Based on the results of the description analysis, it is found that:}

\section{a. Knowledge Management'}

PDAM Ketapang employees tend to more than agree that knowledge management is measured through indicators of knowledge identification, knowledge creation/sources, knowledge sharing and knowledge application. The knowledge identification indicator provides the greatest support for the formation of knowledge management variables, namely the knowledge gained is sufficient to carry out tasks and activities in the PDAM.

\section{b. Competence}

Ketapang PDAM employees tend to more than agree that competence is measured through indicators of task skills, management skills, contingency management skills, transfer skills, and job role environment skills. The task skill indicator provides a major contribution to the formation of competency variables, namely the competence/ability of employees following their respective responsibilities/duties and is following what is needed in the PDAM Ketapang Regency.

\section{c. Innovation}

Ketapang PDAM employees tend to more than agree that innovation consists of indicators of product innovation, process innovation, market innovation and management innovation. The management innovation indicator gives the greatest value to the formation of the innovation variable, namely innovation is carried out by organizational control starting from the Ketapang PDAM (central) to the unit as well as the commitment of the local government to improve the management of PDAM Ketapang Regency for organizational strengthening. 
https://ijbssrnet.com/index.php/ijbssr DOI: 10.47742/ijbssr.v1n2p1

\section{d. Organizational Performance}

PDAM Ketapang employees tend to more than agree with the indicators of output, results, and efforts made compared to the achievement (efficiency) to form organizational performance variables. The output indicators provide a big contribution to the formation of organizational performance variables, namely an increase in the number and customer satisfaction at the PDAM Ketapang Regency.

\section{Based on the results of the path analysis, it is found that:}

a. Knowledge management and competence have a significant positive effect on innovation in PDAM Ketapang Regency.

b. Knowledge management and competence have a significant positive effect on organizational performance in PDAM Ketapang Regency.

c. Innovation has a significant positive effect on organizational performance in PDAM Ketapang Regency.

d. Knowledge management plays a significant positive role in organizational performance through innovation at PDAM Ketapang Regency

e. Competence has a significant positive role in organizational performance through innovation at PDAM Ketapang Regency

f. Knowledge management and competence play a significant positive role in organizational performance through innovation at PDAM Ketapang Regency.

\section{Recommendations}

Based on the above conclusions, the following suggestions can be proposed:

1. To become the basic material for further research related to Human Resources, especially innovation, employee competence, knowledge management and organizational performance and it is hoped that further research will be carried out with a more focused scope in each of the District Capital City SPAM (IKK) units because SPAM IKK in PDAM Ketapang Regency has different problems and challenges.

2. Benefits from research that can be obtained directly by PDAM Ketapang Regency relating to improvements that must be made to overcome problems related to innovation, employee competence, and knowledge management to improve organizational performance by considering:

a. Based on the lowest indicator value on the knowledge management variable, namely the source/knowledge creation indicator, namely using knowledge created/found by employees based on direct experience / in the field and transfer of knowledge among employees as well as conducting evaluation activities on the implementation of knowledge transfer between

http://iarpnet.org/

employees, it is better if the evaluation of the implementation of knowledge transfer is carried out. done on the process, output and outcome. The process is viewed from the method/way of conveying or sharing knowledge. So far, the implementation of knowledge sharing/transfer has been carried out directly in the field. It is better if the implementation of knowledge transfer is also supported by providing understanding or theory. The output of knowledge transfer activities includes the number of employees who get the transfer of knowledge and the amount of material provided. Employees who are the target of knowledge transfer activities should be several employees whose duties are related to the type of knowledge to be shared/transferred. The outcome of the knowledge transfer is seen based on the extent to which the knowledge gained has been implemented in the field, it must be monitored by the employee who transfers the knowledge. If the implementation in the field has not been fully carried out, then evaluate whether the obstacles are and find a solution.

b. Based on the lowest indicator value in the employee competency variable is the transfer of skills, which is using periodic employee transfers and employees must be able to quickly adapt to the new part they are occupying. The implementation of regular employee mutations and the ability of employees to adapt to the newly occupied part, to improve the ability of employees to adapt to the newly occupied section, as well as to increase the meaning of implementing regular mutations on organizational performance, it is necessary to provide an understanding to employees who are transferred regarding Standard Operating Procedures. (SOP) implementation of work in the newly occupied section. Likewise, with the implementation of periodic transfers, an SOP must be made to achieve the expected goals.

c. Based on the lowest indicator value on the innovation variable, namely market innovation, by implementing customer classification and developing service areas at PDAM Ketapang Regency, the proportion of the number of domestic customers (5,685 SL / customer connection) is greater than the number of non-domestic customers (1,952 SL). Domestic customers consist of customers classified as Household A, Household B and Household $\mathrm{C}$, grouped by building area and building location. Meanwhile, non-domestic customers consist of social, commercial and industrial groups. To increase the role in organizational performance, it is necessary to reclassify customers regularly at least once every 3 years, because it will affect PDAM revenue.

d. Based on the lowest indicator value on the organizational performance variable, namely the outcome indicator, namely by increasing the achievement of access to drinking water services and health quality in Ketapang Regency related to the level of customer satisfaction, which is related to customer water quality, operating 
hours and water pressure at customers. To improve customer water quality, PDAM must implement SOPs in the operation and maintenance of Water Treatment Plants, for example cleaning water treatment installations regularly. Meanwhile, to increase service operating hours and customer water pressure, PDAM Ketapang Regency needs to make efforts to increase system capacity, because the capacity of the existing system being utilized is close to the planned capacity. Likewise, http://iarpnet.org/

about improving public health, especially customers, which is related to the quality of water produced in the water treatment unit. To achieve the required water quality, in carrying out the operation and maintenance of the drinking water supply system, especially in the production unit or water treatment installation and distribution unit, it is necessary to carry out operation and maintenance following the SOP.

\section{References}

Afifuddin dan Ahmad Saebani. (2009). Metode Penelitian Kualitatif. Bandung: PT Pustaka Setia Ahmad Saebani, Beni.

Afqarina. (2018). Pengaruh Knowledge Management Dan Organizational Learning Terhadap Kinerja organisasi Melalui Inovasi Sebagai Variabel Intervening. Jurnal Kajian. 27, NO. 1, 2019, 73 - 91

http://jurnal.stieww.ac.id/index.php/jkb/article/view/96/78

Allen dan Meyer, (1990). The Measurement and Antecedents of Affective, Continuance, and Normative Commitment to the Organization. Journal of Occupational Psychology, 63, 1-18. https://onlinelibrary.wiley.com/doi/10.1111/j.20448325.1990.tb00506.x

Anshori, Yusak, (2005). Analisis Keunggulan Bersaing Melalui Penerapan Knowledge Management dan Knowledge-Based Strategy di Surabaya Plaza Hotel, Jurnal Manajemen Perhotelan , Vol. 1, No.2, pp. 39-53. http://jurnalperhotelan.petra.ac.id/index.php/hot/article/view/16307

Arikunto, Suharsimi. (2010). Prosedur Penelitian Suatu pendekatan Praktek. Jakarta: Rineka Cipta.

Arikunto, Suharsini, (2005). Manajemen Penelitian, Edisi Revisi. PT. Rineka Cipta.

Arisman (2015). Peran Mediasi Manajemen Pengetahuan Dalam Peningkatan Kinerja Perusahaan Yang Menggunakan Implementasi

Integrasi Sistem Informasi Akuntansi Di Indonesia. Forum Bisnis Dan Kewirausahaan Jurnal Ilmiah STIE MDP.

http://forbiswira.stie-mdp.ac.id/wp-content/uploads/2015/09/anton.pdf.

Armosudiro, P. (2006). Konsep Organisasi. Jakarta : PT Raja Grafindo Persada.

Creswell, (2016). Research Design Pendekatan Kualitatif, Kuantitatif, dan. Mixed. Yogyakarta: Pustaka Pelajar

Danim, Sudarwan. (2002). Menjadi Peneliti Kualitatif. Bengkulu: Pustaka Setia

Darroch, J dan R McNaughton, (2002). Examining the link between Knowledge Management Practices and Types Innovation, Journal of Intellectual Capital, Vol. 3, No.3 h, 210-222. https://scholarship.claremont.edu/cgu_fac_pub/437/

Darudianto, Setiawan. (2013). Knowledge Management: Konsep dan Metodologi

Drucker, P.F, (1985). Innovation and Entrepreneurship. New York: Harpercollins Publisher

Ekawati dan Puspitowati. (2016). Pengaruh Manajemen Pengetahuan dan Inovasi Terhadap Kinerja Perusahaan UKM Di Jakarta. Conference on Management and Behavioral Studies. http://cmbs.untar.ac.id/images/prosiding/2016/65\%20$\%$ 20Sanny\%20Ekawati.pdf.

Ghozali, Imam. (2011). Aplikasi Analisis Multivariate dengan Program SPSS. Edisi ketiga. Semarang : Badan Penerbit Universitas Diponegoro

Griffin, (2014). Perilaku Organisasi. Jakarta: Salemba Empat.

Halil Zaim, Mehmet Fatih Yasar Ömer Faruk Ünal, (2013). Analyzing The Effects Of Individual Competencies On Performance: A Field Study In Services Industries In Turkey. Journal of Global Strategic Management |V. 7, N. 2, 2013-December, 67-77. DOI: 10.20460/JGSM.2013715668

Hanafi, Ibrahim dan Subyakto. (2019). Analysis of Knowledge Management in Knowledge Sharing and ITS Effect On Innovation Capability In The Operation Department of PUSRI III Plant Pupuk Sriwidjaja Palembang. https://www.semanticscholar.org/paper/ANALYSIS-OF-KNOWLEDGE-MANAGEMENT-IN-KNOWLEDGE-AND-

Ibrahim-Hanafi/9752a8ebad607b858e0b3e7c5aa85aee0d5b65ae

Ibnu. (2017). Inovasi dan Knowledge Management. Jakarta.

Kaswan, (2015). Pengembangan Sumber Daya Manusia . Bandung,. Indonesia : Alfabeta

Komara, (2014). Pengaruh Implementasi Inovasi Pendidikan dan Kompetensi Guru Terhadap Produktivitas Sekolah. Administrasi

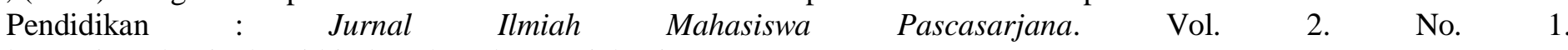
https://jurnal.unigal.ac.id/index.php/adpen/article/view/194.

Mahsun, (2006). Pengukuran Kinerja Sektor Publik,. Penerbit BPFE, Yogyakarta.

Mangkunegara, AA. Anwar Prabu. (2011). Manajemen Sumber Daya Manusia. Bandung : PT. Remaja Rosdakarya 
Mathis dan Jackson, (2012). Manajemen Sumber Daya Manusia, Edisi Pertama

Moeheriono. (2012). Pengukuran Kinerja Berbasis Kompetensi. Jakarta: PT Raja Grafindo Persada

Moleong, J. Lexy. (2007). Metodologi Penelitian Kualitatif. Bandung: Remaja Rosdakarya.

Noviyanti dan Mulyanto. (2017). Pengaruh Knowledge Management Terhadap Inovasi, Implementasi Strategi dan Kinerja

Organisasi (Studi Pada RS Lavalette Malang). Berkala Akuntansi dan Keuangan Indonesia, Vol. 02, No. 02 (2017): 21-38 https://e-journal.unair.ac.id/BAKI/article/view/5325

Nurjanah. (2015). Peranan Manajemen Inovasi Dalam Meningkatkan Kinerja Organisasi pendidikan. Conference In Business, Accounting, And Management (CBAM). Vol. 2. No. 1. http://jurnal.unissula.ac.id/index.php/cbam/article/view/288.

Osei, (2015). Employee's Competency and Organizational Performance In The Pharmaceutical Industry an Empirical Study of Pharmaceutical Firms in Ghana. International Journal of Economics, Commerce and Management United Kingdom Vol. III, Issue 3, March 2015.

https://www.researchgate.net/profile/Owusu_Ackah/publication/303689816_International_Journal_of_Economics_Comm erce_and_Management_EMPLOYEE'S_COMPETENCY_AND_ORGANIZATIONAL_PERFORMANCE_IN_THE_PH ARMACEUTICAL_INDUSTRY_AN_EMPIRICAL_STUDY_OF_PHARMACEUTICAL_FIRMS_IN_GHANA/links/5 74daad508ae82d2c6be00fd/International-Journal-of-Economics-Commerce-and-Management-EMPLOYEES-

COMPETENCY-AND-ORGANIZATIONAL-PERFORMANCE-IN-THE-PHARMACEUTICAL-INDUSTRY-AN-

EMPIRICAL-STUDY-OF-PHARMACEUTICAL-FIRMS-IN-GHANA.pdf.

Prajogo DI. (2006). The Relationship between Innovation and Business Performance - A Comparative Study between Manufacturing and Service Firms. Knowledge Process Management. 13(3):218-25. https://onlinelibrary.wiley.com/doi/abs/10.1002/kpm.259.

Priyatno, Duwi. (2014). SPSS 22 Pengolah Data Terpraktis. Andi. Yogyakarta.

Purgiantoro, Jamaaludin. (2018). Pengaruh Pewirausaha Yang Memiliki Kompetensi Kewirausahaan Pada Kesuksesan Inovasi Produk dan Kinerja Bisnis Sebagai Penopang Kemajuan Bangsa. IOP Conf. Series: Materials Science and Enginee1ri2n3g44348(9200'1'8“)”012209 doi:10.1088/1757-899X/434/1/012209.http://eprints.umsida.ac.id/7249/

Puryantini, Arfati danTjahjadi. (2017). Pengaruh Knowledge Management Terhadap Kinerja Organisasi Dimediasi Inovasi di Organisasi Penelitian Pemerintah. Berkala Akuntansi dan Keuangan Indonesia, Vol. 02, No. 02 (2017): 21-38. Users/User/Downloads/5325-18539-1-PB.pdf

Riduwan, (2010). Skala Pengukuran Variabel-variabel Penelitian. Bandung: Alfabeta.

Riduwan, (2012). Metode \& Teknik Menyusun Proposal Penelitian. Bandung: Alfabeta.

Rivai, Veithzal. (2003). Kepemimpinan dan Perilaku Organisasi (Edisi Kedua) Jakarta : PT. Raja Grafindo Persada

Rivai, Veitzal. (2012). Manajemen Sumber Daya Manusia Untuk Perusahaan Dari Teori Ke Praktek. PT. Rajagrafindo Persada, Jakarta

Robbins, Stephen P. dan Judge, (2012), Organizational Behavior. Edition 15. New Jersey: Pearson Education

Rustia dan Sugito (2017). Mendongkrak Kinerja Inovasi Melalui Manajemen Pengetahuan Dan Kecakapan Organisasional Dengan Mediasi Orientasi Kewirausahaan. Jurnal Studi Manajemen dan Bisnis. Vol. $4 . \quad$ No. 1. https://journal.trunojoyo.ac.id/jsmb/article/view/3226.

Saraswati, Widiartono. 2016. Pengaruh Implementasi Knowledge Management Terhadap Kinerja Organisasi Melalui Inovasi Sebagai Variabel Intervening. Jurnal Ilmu Administrasi Bisnis. Vol. $4 \quad$ No. 5 . https://ejournal3.undip.ac.id/index.php/jiab/article/view/13567.

Sarwono, Jonathan. (2015). Metode Riset Skripsi Pendekatan Kuantitatif. Menggunakan Prosedur SPSS (Edisi Pertama). Jakarta: PT Elexmedia komputindo

Schumpeter, J.A, (1934). The Theory of Economic Development. Cambridge: Harvard University Press.

Siagian. (2019). Pengaruh Strategi Knowledge Management Dan Inovasi Terhadap Kinerja Organisasi PT. KCJ (Kereta Commuter Jabodetabek). https://repository.ipb.ac.id/handle/123456789/98213

Siregar, Syofian, (2013). Metode Penelitian Kuantitatif Dilengkapi Dengan Perbandingan Perhitungan Manual \& SPSS. Jakarta: Kencana

Sudarmanto. 2009. Kinerja dan Pengembangan Kompetensi SDM. Yogyakarta : Pustaka Pelajar.

Sugiyono, (2008), Metode Penelitian Kuantitatif, Kualitatif dan R\&D, Bandung : Alfabeta 2008. Metode Penelitian. Bandung: Pustaka Setia

Sugiyono. (2017). Metode Penelitian Kuantitatif, Kualitatif, dan R\&D. Bandung : Alfabeta, CV.

Umam. Khaerul. (2010). Perilaku Organisasi. Bandung : Pustaka Setia

Wibawa, (2010). Manajemen Kinerja, Edisi Ketiga, Jakarta, Rajawali Press,

Widayana, Lendy, (2005). Knowledge Management Meningkatkan Daya Saing Bisnis, Bayumedia Publishing, Malang 